\title{
An Export Portfolio Assessment of Regional Free Trade Agreements: A Mercosur and Pacific Alliance Perspective
}

\author{
Raul de Gouvea1, Dimitri Kapelianis², Manuel-Julian R. Montoya' ${ }^{1}$, Gautam Vora1 \\ ${ }^{1}$ Department of FIT Management, Anderson School of Management, University of New Mexico, Albuquerque, \\ USA \\ ${ }^{2}$ Department of MIDS, Anderson School of Management, University of New Mexico, Albuquerque, USA \\ Email: rauldg@unm.edu, dkapeli@unm.edu, mrmonto@unm.edu, vora@unm.edu
}

Received 25 February 2014; revised 18 April 2014; accepted 30 April 2014

Copyright (C) 2014 by authors and Scientific Research Publishing Inc.

This work is licensed under the Creative Commons Attribution International License (CC BY).

http://creativecommons.org/licenses/by/4.0/

(c) (i) Open Access

\begin{abstract}
We use the portfolio theory to assess the export performance of two important regional free trade agreements (RFTAs), namely, Mercosur and the Pacific Alliance, and their constituent countries. The results indicate that the export portfolio of the Pacific Alliance dominates that of Mercosur from a risk-return perspective. When we compare these two regional FTAs' portfolios to an Asian export portfolio, the performance of the export portfolios of the Latin American RFTAs is dominated by that of the Asian export portfolio. In a larger context, the continual attention paid to these Latin American RFTAs is a reflection of the slow and uneven development of global trade negotiation.
\end{abstract}

\section{Keywords}

Export Performance, Free Trade Area, Regional Free Trade Area, Single Index Model, Sharpe Measure

\section{Introduction}

The past decades have seen the expansion of bilateral free trade agreements (BFTAs) and regional free trade agreements (RFTAs) across the globe. The United Nations Conference on Trade and Employment negotiated the Havana Charter of the then-defunct International Trade Organization (ITO) which was not ratified by the US and whose principles later became part of the charter in 1947 of the General Agreement on Tariffs and Trade (GATT). The purpose of GATT was reducing tariffs and various trade barriers and the elimination of preferen- 
tial trade activity between traditional trading partners. In 1995 GATT was superseded by the World Trade Organization (WTO) which is intended to supervise international trade with the aim of liberalizing it. The objectives of the WTO follow from the widely accepted view that international trade has positive impacts on employment, poverty and prosperity. However, the slow progress on the Doha round of multilateral trade negotiations, initiated in November 2001, on subjects as diverse as tariffs, non-tariff measures, agriculture, labor standards, environment, investments, transparency, and settlement of trade disputes has provided a new momentum for the development and expansion of bilateral free trade agreements (BFTAs) and regional free trade agreements (RFTAs). Although the Doha round has not concluded, an intermediate step called the Bali Package was signed in December 2013. The main thrust of the Bali package is trade facilitation measures expected to result in removing red tape and expediting customs procedures, thereby lowering the transaction cost of export and import procedures. In addition, it manages import tariffs and export subsidies. As of July 2013, 379 regional trade agreements have been implemented ([1]-[3]). Numerous countries have realized that they can obtain trade benefits in a shorter time frame by engaging in BFTAs and RFTAs. Moreover, countries also have other non-trade objectives such as realizing political and strategic goals by embracing in this second-best solution to global trade ([4] [5]).

The dissatisfaction of numerous emerging economies with GATT was carried over to the WTO. These countries felt that their major international trade aspirations were not being adequately addressed. The creation of the WTO was aimed at reforming the global trading system and attempted to provide a new impetus and momentum for emerging economies. This objective was initially well-received by emerging and developed nations. In 2001 a new round of trade negotiations was launched. The Doha Development Agenda was initially perceived as a way to address a number of trade concerns of emerging economies as well as of developed countries. However, the "Doha Light" concessions raised a number of sensitivities amongst WTO members, leading to the current stalemate on global multilateral trade negotiations ${ }^{1}$. Opposing views on the reduction of agriculture tariffs and subsidies by developed countries and how emerging economies should revise the guidelines for market access to their manufacturing industries and service sector are the root cause of these current disputes. The "Doha Light" may be interpreted as a signature failure of the WTO to deliver a fully global multilateral trade agreement.

As a result of widely different perspectives on international trade and trade disputes amongst WTO members and non-WTO members, the global economy is moving increasingly towards the expansion of preferential trade initiatives, outside the WTO guidelines, such as the Trans-Pacific Partnership (TPP) ${ }^{2}$ and the Transatlantic Free Trade Area (TAFTA) discussions. These discussions were previously based on the Transatlantic Trade and Investment Partnership (TTIP) ${ }^{3}$ proposals which not only aimed to address customs barriers but also sought to standardize technical regulations and other transaction costs not normally accounted for by larger trade discussions ([6]-[10]).

\section{Literature Review}

\subsection{Regional Integration}

The modern history of regional cooperation in trade and commerce can be said to start with the recognition of success of the European Union (EU) ${ }^{4}$. It is important, however, to recognize that EU is more than a free trade

\footnotetext{
${ }^{1}$ See “'Doha Light' takes shape as WTO members lower ambitions” at the International Centre for Trade and Sustainable Development (http://ictsd.org/i/news/bridgesweekly/107865/).

${ }^{2}$ It is a "free trade deal" among the three countries of North America (viz., the US, Canada and Mexico), eight countries in the Asia-Pacific region (viz., Australia, Brunei, Japan, Korea, Malaysia, New Zealand, Singapore, and Vietnam) and two countries in Latin American (viz., Chile and Peru). It began as an agreement among Brunei, Singapore, New Zealand, Chile, until the US took the leadership role in 2009. See Washington Post (2013, Dec. 11, at

http://www.washingtonpost.com/blogs/wonkblog/wp/2013/12/11/everything-you-need-to-know-about-the-trans-pacific-partnership/). ${ }^{3}$ See, for example, http://ec.europa.eu/trade/policy/in-focus/ttip/ and http://www.ustr.gov/about-us/press-office/fact-sheets/2013/june/wh-ttip. ${ }^{4}$ If we ignore the unpleasant history of colonialism which saw economic integration of the highest order among numerous countries regardless of bonds of common history or geography, the discussion of "regional integration" began in Europe in the post-World War II years of the fifties. The European Coal and Steel Community was the forerunner of other political and economic pressures propelling the countries of Europe towards some integration. The main impetus was political, not economic: Europeans were determined to prevent a repeat of killing and destruction of their countries. West European countries created the Council of Europe in 1949, but six countries of Germany, France, Italy, the Netherlands, Belgium and Luxembourg signed a treaty in 1951 to run their heavy industries under a common management so that no single country can individually make the weapons of war. Building on the success of the Coal and Steel Treaty the same six countries signed in 1957 the Treaty of Rome creating the European Economic Community (EEC), more commonly known as "common market". As the decades progressed, more countries joined the common market and in 1993 the Maastricht Treaty established the European Union (EU) under its current name.
} 
agreement; in fact, it is a system of supranational independent institutions and intergovernmental negotiated decision-making. It is clear that European leaders recognized that institutional arrangement would make the movement of raw materials, laborers, and business transactions easier thereby making post-war recovery less cumbersome and more effective ([11] [12]). Besides the urgency of rebuilding Europe within a reasonable timeframe, these interactions achieved two goals. First, it encouraged economies highly susceptible to external influence to participate in international trade. Second, it encouraged other nations to participate in similar agreements ([13] [14]). Regional integration has been viewed as the vehicle for peace and economic growth and development, establishing the circumstances needed to establish social, political, and cultural cooperation ([15] $[16])$.

The success of EU experiment has given rise to an interesting debate regarding the value of regional integration as a laboratory for the development of a world economy ${ }^{5}$. This discourse has become increasingly popular as the world turns its attention to emerging economies, for instance, the development of a new African economic agenda set in part by South Africa and the renewed role that India and China have played among smaller Asian economies ([17] [18]). These perspectives draw upon a common inquiry: what is the stitching that binds economies together and how does that help in understanding the evolution of the global economy?

Regional free trade agreements reflect the perceived injustice in expansive institutional policies of GATT, WTO and other international institutions as well as the frustration emerging economies feel about the inertia and apparent protectionism in supranational negotiations. Hence, the ideological stitching that binds the world economy remains focused on cooperation among the parts rather than the whole. Latin American regional FTAs help us understand how economies are motivated by a desire to participate in a world economy but are frustrated with the world economy's ability to include its diverse parts ${ }^{6}$.

\subsection{Latin American Regional FTAs}

Between the 1960s and early 1990s, Latin American countries devised a number of regional FTAs. Most of these initiatives did not result in substantial trade improvements for these country members. A combination of autarchic economic models, lack of political transparency and economic instability did not provide the fertile ground for the growth of these regional FTAs in the region. In the 1990s, however, Latin American countries saw a dramatic change taking place. Several Latin American countries such as Argentina, Brazil and Mexico embraced market-oriented reforms and a new desire for freer trade policies and strategies shaped the economic agenda of the region. In the 1990s, the creation of Mercosur, the addition of Mexico to NAFTA, and the revival of aging trading blocs throughout Latin America provided a new momentum for the region.

In the 2000s, the unsuccessful Doha Round of multilateral trade negotiations has also given rise to the emergence of a number of RFTAs in Latin America ([21]). The creation of the Pacific Alliance FTA further demonstrated that the region is becoming more interested in global trade. It is true that the rise of protectionist measures have become more pervasive in the past few years, as in the case of Argentina, but there exists an undeniable interest in international trade as evidenced by the creation in 1975 of the Latin American and Caribbean Economic System (better known as SELA from its official name, Sistema Económico Latinoamericano y del Caribe $)^{7}$.

The creation of an RFTA is expected to generate economic efficiency for the members involved such that the benefits of trade creation exceed the costs of trade distortion. These net benefits are expected to accrue more from regional trade than from international trade. For long-term benefits the regional trade would need to be growing and steady. This means that exports of the member-countries should be characterized by a steady growth and lower volatility. The Latin American RFTAs provide a natural "experiment"; an examination of the export performance of Mercosur and the Pacific Alliance should provide insights into the efficacy of forming trade alliances.

\footnotetext{
${ }^{5}$ On the one hand, neo-liberals' argument is that a fair worldwide system could not evolve while some powerful sovereign countries play a central, dominating, agenda-setting role. On the other hand, structuralists' argument is that new ways of socio-economic being and belonging to the world (such as the development of new spaces for public participation and discourse, importance of civic engagement at national and international levels, and a sense of personal and national security) would create the institutional and infrastructural elements needed for a fuller and mutually beneficial cooperation.

${ }^{6}$ For an Asian perspective, see Chow and Ciuriak ([19]) and Haokip ([20]) and references therein.

${ }^{7}$ Sela is a regional intergovernmental organization of 28 Latin American and Caribbean countries. (For more information see http://sela.org/view/index.asp?ms=258\&pageMs=26475.)
} 


\section{Profiles of Mercosur and the Pacific Alliance}

Table 1 gives an overview of Mercosur and the Pacific Alliance ${ }^{8}$. Mercosur comprises Argentina, Brazil, Paraguay, Uruguay and Venezuela. The Pacific Alliance comprises Chile, Colombia, Mexico and Peru. The countries of Mercosur and the Pacific Alliance have the largest share of Latin American GDP: the share of Mercosur is US \$3.3 trillion whereas that of the Pacific Alliance is US \$2 trillion. The population of Mercosur is close to 270 million and that of the Pacific Alliance is close to 205 million. Thus both blocs have large regional markets for which to build goods and services. In 2012 the exports of Mercosur were US $\$ 445$ billion whereas those of the Pacific Alliance were US \$524 billion. Finally, Table 1 summarizes the ratio of exports to GDP for the countries of Mercosur and the Pacific Alliance. Countries like Brazil (19\%) and Argentina (33.6\%) still show uninspiring ratios compared to countries like Chile (61.3\%) and Mexico (60.4\%). To a large extent, these ratios show the countries' commitment to international trade and open economy.

Table 2 gives the export structure of the countries of Mercosur and the Pacific Alliance. A striking similarity is the extreme dependence on natural-resource-based goods. Mexico is the only exception in two blocs, showing a $70 \%$ share of manufactured products among its total exports. Countries like Chile and Venezuela show a very small percentage of manufactured products in their export portfolios (13\% and $12.3 \%$ respectively).

Mercosur countries offer a large regional market, with low levels of trade-to-GDP ratio, mainly for its largest economies, viz., Argentina and Brazil. Mercosur heavily depends on natural-resource goods for the large majority of its exports. The trading bloc has been able to develop higher levels of regional trade than has been the Pacific Alliance. A weakness is that it shows an extreme dependence on a few markets for the majority of its exports.

Table 1. Summary statistics for Mercosur and Pacific Alliance.

\begin{tabular}{ccccccccccc}
\hline Variable & \multicolumn{1}{c}{ Mercosur } & \multicolumn{3}{c}{ Pacific Alliance } \\
\hline & Argentina & Brazil & Paraguay & Uruguay & Venezuela & Chile & Colombia & Mexico & Peru \\
\hline Population (MM) & 40 & 192 & 6 & 3 & 27 & 17 & 46 & 112 & 30 \\
GDP (US\$ MM) & 445,989 & $2,476,652$ & 23,877 & 46,710 & 316,482 & 248,585 & 331,655 & $1,155,316$ & 176,662 \\
GDP per capita (US\$) & 14,700 & 10,800 & 5200 & 13,700 & 12,700 & 15,400 & 9800 & 13,900 & 9200 \\
Total exports (US\$ billion) & 84 & 250 & 10 & 8 & 93 & 86 & 56 & 336 & 46 \\
Human development index & 45 & 84 & 107 & 48 & 73 & 44 & 87 & 57 & 80 \\
Corruption perception index & 100 & 73 & 154 & 25 & 172 & 22 & 80 & 100 & 80 \\
Competitiveness index & 85 & 53 & 122 & 63 & 124 & 31 & 68 & 58 & 67 \\
Ease-of-doing-business index & 113 & 126 & 102 & 90 & 177 & 39 & 47 & 53 & 41 \\
Index of economic freedom & 158 & 99 & 79 & 29 & 174 & 7 & 45 & 54 & 42 \\
Environmental index & 50 & 30 & 73 & 46 & 56 & 58 & 27 & 84 & 81 \\
Country risk ranking & 90 & 41 & 96 & 75 & 93 & 27 & 51 & 53 & 58 \\
FDI (US\$ billion) & 6.3 & 65.5 & 0.26 & 2.53 & 5.3 & 17.6 & 14.4 & 7.9 & 17.9 \\
Trade-to-GDP ratio & $33.6 \%$ & $19.0 \%$ & $80.8 \%$ & $49.3 \%$ & $33.5 \%$ & $61.3 \%$ & $27.6 \%$ & $39.3 \%$ & $60.4 \%$ \\
\hline
\end{tabular}

Notes: The statistics are for the year 2011. The FDI for Paraguay is for the year 2010. Trade-to-GDP ratio is for the year 2010. Sources: country risk ranking: Euromoney (out of 100 countries); population: CIA Factbook; GDP and GDP per capita: IMF/World Bank; total exports: unctad; human development index: United Nations; corruption perception index: transparency international; competitiveness index: world economic forum; ease of doing business: World Bank; index of economic freedom: heritage foundation; environmental index: Yale University; foreign direct investment: unctad Global Investment Trends Monitor, No. 8, 2012; Trade-to-GDP ratio: DG trade, March 21, 2012 and EuroStat, 2012.

\footnotetext{
${ }^{8}$ The statistics are for the year 2011. The FDI for Paraguay is for the year 2010. Trade-to-GDP ratio is for the year 2010. These and other statistics are sourced as follows: country risk ranking: Euromoney (out of 100 countries); population: CIA Factbook; GDP and GDP per capita: IMF/World Bank; total exports: unctad; human development index: United Nations; corruption perception index: transparency international; competitiveness index: world economic forum; ease of doing business: World Bank; index of economic freedom: heritage foundation environmental index: Yale University; foreign direct investment: unctad Global Investment Trends Monitor, No. 8, 2012; Trade-to-GDP ratio: DG trade, March 21, 2012 and EuroStat, 2012.
} 
Table 2. Trade structure of Mercosur and the Pacific Alliance.

\begin{tabular}{|c|c|c|c|c|c|c|}
\hline & $\begin{array}{l}\text { All food } \\
\text { items }\end{array}$ & $\begin{array}{l}\text { Agricultural raw } \\
\text { materials }\end{array}$ & Fuels & $\begin{array}{l}\text { Ores, } \\
\text { metals }\end{array}$ & Manufactured & $\begin{array}{l}\text { High-tech } \\
\text { exports }\end{array}$ \\
\hline \multicolumn{7}{|l|}{ Mercosur } \\
\hline Argentina & 52.7 & 1.2 & 5.9 & 6.6 & 31.5 & 8 \\
\hline Brazil & 30.2 & 3.5 & 10.5 & 20.9 & 32.9 & 10 \\
\hline Paraguay & 85.2 & 2.3 & 0.2 & 1.5 & 10.7 & 7 \\
\hline Uruguay & 55.4 & 15.3 & 1.5 & 1.4 & 26.4 & 6 \\
\hline Venezuela & 0.3 & 0.1 & 84.3 & 2.9 & 12.3 & 2 \\
\hline \multicolumn{7}{|c|}{ Pacific Alliance } \\
\hline Chile & 17.6 & 5.8 & 1 & 62.6 & 13 & 5 \\
\hline Colombia & 10 & 2.3 & 64.1 & 6.3 & 17.2 & 4 \\
\hline Mexico & 6.2 & 0.4 & 15.9 & 6.2 & 70.7 & 17 \\
\hline Peru & 16.3 & 0.9 & 11 & 61 & 10.7 & 6 \\
\hline \multicolumn{7}{|c|}{ HISSK countries } \\
\hline Indonesia & 16.2 & 7.5 & 33.9 & 8.9 & 33.6 & 8 \\
\hline Singapore & 2.1 & 0.3 & 19.8 & 1.8 & 68.1 & 45 \\
\hline S. Korea & 1.1 & 1.2 & 9.6 & 2.9 & 85.3 & 26 \\
\hline
\end{tabular}

Notes: All figures are percentages, data on high tech exports are from World Bank, 2011, http://data.worldbank.org, all other data are from UNCTAD Handbook of Statistics 2012.

Another major feature of Mercosur economies is the low share of high-tech goods and services as a share of total exports. Amongst Mercosur members, Brazil shows the largest share of high-tech exports, approximately $10 \%$, Argentina approximately $8 \%$ and Venezuela approximately $2 \%$. Among the Pacific Alliance members performance is a little better, with Mexico showing approximately $17 \%$ for high-tech exports and Chile approximately $5 \%$.

An implication is that Latin American countries are on the "wrong" side of the innovation stream. This is expected to create additional problems for their long-term competitiveness in international trade. In today's knowledge-driven global economy, countries that do not invest adequately in education, infrastructure, civil society institutions, innovation and commercial and industrial efforts of research and development steadily become less attractive to multi-national corporations which are developing their global supply chains as well as markets thereby restricting export growth by these countries. These inadequate investments ultimately show up in export performance.

Table 3 shows the main trading partners of the trading blocs. The table lists countries with shares larger than $0.2 \%-0.3 \%$. Table 3(a) shows that for Mercosur, the European Union, China, USA and Mercosur countries constitute its main trading partners on the import and export side. It is important to highlight that Brazil shows a much lower dependence on the Mercosur market for its exports than do the other Mercosur member countries. Table 3(b) shows that for the Pacific Alliance, the imports from and exports to its members constitute only a small share of their countries' total trade. Similar to Mercosur, for the Pacific Alliance the European Union, China, and USA are the largest trading partners.

In 2012 the exports of the members of Mercosur were approximately US \$424 billion whereas those of the members of the Pacific Alliance were approximately US \$546.832 billion. In 2012, Mercosur’s export portfolio shows a strong dominance of Brazilian exports, accounting for $57.1 \%$ of Mercosur's total exports, followed by Venezuela with $21.5 \%$, Argentina with $0.19 \%$, and Uruguay with $2.3 \%$ of the bloc's total exports. In the Pacific Alliance trading bloc, Mexico has the dominance accounting for approximately to $67.5 \%$ of the bloc's total exports followed by Chile with $14.3 \%$, Colombia with $11.0 \%$ and Peru with $7.0 \%$. 
Table 3. (a) Main trading partners of Mercosur (percent of total trade), (b) Main trading partners of the Pacific Alliance (percent of total trade).

(a)

\begin{tabular}{|c|c|c|c|c|c|c|c|c|c|}
\hline \multicolumn{2}{|c|}{ Argentina } & \multicolumn{2}{|c|}{ Brazil } & \multicolumn{2}{|c|}{ Paraguay } & \multicolumn{2}{|c|}{ Uruguay } & \multicolumn{2}{|c|}{ Venezuela } \\
\hline Imports & Exports & Imports & Exports & Imports & Exports & Imports & Exports & Imports & Exports \\
\hline $\begin{array}{c}\text { Brazil: } \\
32.0\end{array}$ & $\begin{array}{c}\text { Brazil: } \\
21.2\end{array}$ & $\begin{array}{c}\text { EU27: } \\
21.9\end{array}$ & $\begin{array}{c}\text { EU27: } \\
21.5\end{array}$ & $\begin{array}{c}\text { China: } \\
34.7\end{array}$ & $\begin{array}{c}\text { Uruguay: } \\
21.9\end{array}$ & $\begin{array}{c}\text { Argentina: } \\
14.8\end{array}$ & $\begin{array}{c}\text { EU27: } \\
20.2\end{array}$ & $\begin{array}{l}\text { USA: } \\
31.3\end{array}$ & $\begin{array}{l}\text { USA: } \\
39.6\end{array}$ \\
\hline $\begin{array}{c}\text { EU27: } \\
17.4\end{array}$ & $\begin{array}{c}\text { EU27: } \\
16.4\end{array}$ & $\begin{array}{l}\text { USA: } \\
15.3\end{array}$ & $\begin{array}{c}\text { China: } \\
15.5\end{array}$ & $\begin{array}{c}\text { Brazil: } \\
24.4\end{array}$ & $\begin{array}{c}\text { Brazil: } \\
14.5\end{array}$ & $\begin{array}{c}\text { Brazil: } \\
14.1\end{array}$ & $\begin{array}{c}\text { Brazil: } \\
19.8\end{array}$ & $\begin{array}{c}\text { EU27: } \\
13.3\end{array}$ & $\begin{array}{c}\text { India: } \\
7.8\end{array}$ \\
\hline $\begin{array}{c}\text { China: } \\
13.7\end{array}$ & $\begin{array}{c}\text { China: } \\
8.6\end{array}$ & $\begin{array}{c}\text { China: } \\
14.3\end{array}$ & $\begin{array}{l}\text { USA: } \\
9.7\end{array}$ & $\begin{array}{c}\text { Argentina: } \\
15.6\end{array}$ & $\begin{array}{c}\text { Chile: } \\
12.0\end{array}$ & $\begin{array}{c}\text { China: } \\
13.7\end{array}$ & $\begin{array}{c}\text { China: } \\
13.3\end{array}$ & $\begin{array}{l}\text { China: } \\
9.3\end{array}$ & $\begin{array}{c}\text { China: } \\
7.6\end{array}$ \\
\hline $\begin{array}{l}\text { USA: } \\
10.9\end{array}$ & $\begin{array}{c}\text { Chile: } \\
6.6\end{array}$ & $\begin{array}{c}\text { Argentina: } \\
8.1\end{array}$ & $\begin{array}{c}\text { Argentina: } \\
9.2\end{array}$ & $\begin{array}{c}\text { EU27: } \\
5.3\end{array}$ & $\begin{array}{c}\text { Argentina: } \\
11.8\end{array}$ & $\begin{array}{c}\text { EU27: } \\
11.8\end{array}$ & $\begin{array}{c}\text { Argentina: } \\
7.0\end{array}$ & $\begin{array}{c}\text { Brazil: } \\
9.3\end{array}$ & $\begin{array}{c}\text { Uruguay: } \\
1.1\end{array}$ \\
\hline $\begin{array}{c}\text { Mexico: } \\
3.3\end{array}$ & $\begin{array}{l}\text { USA: } \\
5.4\end{array}$ & $\begin{array}{c}\text { Chile: } \\
2.3\end{array}$ & $\begin{array}{c}\text { Chile: } \\
2.1\end{array}$ & $\begin{array}{l}\text { USA: } \\
4.4\end{array}$ & $\begin{array}{c}\text { EU27: } \\
10.7\end{array}$ & $\begin{array}{c}\text { Paraguay: } \\
9.2\end{array}$ & $\begin{array}{c}\text { Venezuela: } \\
4.3\end{array}$ & $\begin{array}{c}\text { Colombia: } \\
4.7\end{array}$ & $\begin{array}{c}\text { Brazil: } \\
0.7\end{array}$ \\
\hline $\begin{array}{c}\text { Chile: } \\
1.6\end{array}$ & $\begin{array}{c}\text { Uruguay: } \\
2.4\end{array}$ & $\begin{array}{c}\text { Mexico: } \\
2.2\end{array}$ & $\begin{array}{c}\text { Venezuela: } \\
1.9\end{array}$ & $\begin{array}{c}\text { Venezuela: } \\
2.2\end{array}$ & $\begin{array}{c}\text { Peru: } \\
2.8\end{array}$ & $\begin{array}{l}\text { USA: } \\
9.0\end{array}$ & $\begin{array}{c}\text { Mexico: } \\
2.9\end{array}$ & $\begin{array}{c}\text { Mexico: } \\
4.4\end{array}$ & $\begin{array}{c}\text { Colombia: } \\
0.4\end{array}$ \\
\hline $\begin{array}{c}\text { Uruguay: } \\
1.1\end{array}$ & $\begin{array}{c}\text { Venezuela: } \\
2.1\end{array}$ & $\begin{array}{c}\text { Uruguay: } \\
0.9\end{array}$ & $\begin{array}{c}\text { Mexico: } \\
1.9\end{array}$ & $\begin{array}{c}\text { Uruguay: } \\
1.5\end{array}$ & $\begin{array}{c}\text { Venezuela: } \\
2.5\end{array}$ & $\begin{array}{c}\text { Venezuela: } \\
\quad 6.5\end{array}$ & $\begin{array}{c}\text { USA: } \\
2.9\end{array}$ & $\begin{array}{c}\text { Argentina: } \\
3.5\end{array}$ & $\begin{array}{c}\text { Mexico: } \\
0.3\end{array}$ \\
\hline $\begin{array}{c}\text { Paraguay: } \\
0.8\end{array}$ & $\begin{array}{c}\text { Colombia: } \\
1.9\end{array}$ & $\begin{array}{c}\text { Colombia: } \\
0.6\end{array}$ & $\begin{array}{c}\text { Paraguay: } \\
1.3\end{array}$ & $\begin{array}{c}\text { Chile: } \\
1.2\end{array}$ & $\begin{array}{c}\text { USA: } \\
1.5\end{array}$ & $\begin{array}{c}\text { Mexico: } \\
1.9\end{array}$ & $\begin{array}{c}\text { Paraguay: } \\
1.8\end{array}$ & $\begin{array}{c}\text { Chile: } \\
1.8\end{array}$ & $\begin{array}{c}\text { Argentina } \\
0.3\end{array}$ \\
\hline $\begin{array}{c}\text { Colombia: } \\
0.3\end{array}$ & $\begin{array}{c}\text { Mexico: } \\
1.8\end{array}$ & $\begin{array}{c}\text { Peru: } \\
0.5\end{array}$ & $\begin{array}{c}\text { Colombia: } \\
1.1\end{array}$ & $\begin{array}{c}\text { Mexico: } \\
0.9\end{array}$ & $\begin{array}{c}\text { China: } \\
0.7\end{array}$ & $\begin{array}{c}\text { Chile: } \\
1.4\end{array}$ & $\begin{array}{c}\text { Chile: } \\
1.7\end{array}$ & $\begin{array}{c}\text { Uruguay: } \\
1.2\end{array}$ & $\begin{array}{c}\text { Peru: } \\
0.1\end{array}$ \\
\hline $\begin{array}{c}\text { Peru: } \\
0.2\end{array}$ & $\begin{array}{c}\text { Paraguay: } \\
1.7\end{array}$ & $\begin{array}{c}\text { Venezuela: } \\
0.5\end{array}$ & $\begin{array}{c}\text { Peru: } \\
1.0\end{array}$ & $\begin{array}{c}\text { Colombia: } \\
0.1\end{array}$ & $\begin{array}{c}\text { Mexico: } \\
0.2\end{array}$ & $\begin{array}{c}\text { Peru: } \\
0.2\end{array}$ & $\begin{array}{c}\text { Peru: } \\
1.2\end{array}$ & $\begin{array}{c}\text { Paraguay: } \\
0.1\end{array}$ & $\begin{array}{c}\text { Chile: } \\
0.0\end{array}$ \\
\hline $\begin{array}{c}\text { Venezuela: } \\
0.0\end{array}$ & $\begin{array}{c}\text { Peru: } \\
1.7\end{array}$ & $\begin{array}{c}\text { Paraguay: } \\
0.3\end{array}$ & $\begin{array}{c}\text { Uruguay: } \\
0.8\end{array}$ & $\begin{array}{c}\text { Peru: } \\
0.0\end{array}$ & $\begin{array}{c}\text { Colombia: } \\
0.1\end{array}$ & $\begin{array}{c}\text { Colombia: } \\
0.1\end{array}$ & $\begin{array}{c}\text { Colombia: } \\
0.7\end{array}$ & & \\
\hline
\end{tabular}

Notes: data are from IMF, 2012. The table lists countries with shares larger than $0.2 \%-0.3 \%$. The members of Mercosur are given in bold typeface.

(b)

\begin{tabular}{ccccccccc}
\hline & \multicolumn{2}{c}{ Chile } & \multicolumn{2}{c}{ Colombia } & \multicolumn{2}{c}{ Mexico } & \multicolumn{2}{c}{ Peru } \\
\hline Imports & Exports & Imports & Exports & Imports & Exports & Imports & Exports \\
\hline China: & China: & USA: & USA: & USA: & EU27: & USA: & USA: \\
17.7 & 25.3 & 26.0 & 43.1 & 24.5 & 20.7 & 49.0 & 80.1 \\
USA: & EU27: & EU27: & EU27: & China: & China: & China: & EU27: \\
17.7 & 17.8 & 14.1 & 12.6 & 13.0 & 18.5 & 15.4 & 4.8 \\
EU27: & USA: & China: & China: & EU27: & USA: & EU27: & China: \\
13.7 & 10.2 & 13.6 & 5.1 & 10.1 & 16.2 & 10.7 & 1.4 & Brazil: \\
Argentina: & Brazil: & Mexico: & Venezuela: & Brazil: & Chile: & Brazil: & 1.3 & 1.3 \\
8.4 & 6.3 & 9.6 & 3.6 & 7.4 & 4.2 & Chile: & Colombia: \\
Brazil: & Mexico: & Brazil: & Peru: & Chile: & Brazil: & Chil: & 0.7 & 1.3 \\
8.4 & 2.7 & 5.9 & 2.9 & 6.0 & 3.0 & Chile: \\
Mexico: & Peru: & Argentina: & Brazil: & Colombia: & Colombia: & Argentina: & Chile \\
3.8 & 2.4 & 3.7 & 2.6 & 4.1 & 2.4 & 0.4 & 0.6 \\
Colombia: & Argentina: & Peru: & Chile: & Argentina: & Venezuela: & Colombia: & Argentina: \\
2.8 & 1.5 & 1.9 & 2.3 & 4.1 & 1.6 & 0.3 & 0.6 \\
Peru: & Colombia: & Chile: & Mexico: & Mexico: & Mexico: & Venezuela: & Venezuela: \\
2.5 & 1.1 & 1.8 & 1.6 & 3.6 & 1.1 & 0.2 & 0.5 \\
Paraguay: & Venezuela: & Venezuela: & Argentina: & Paraguay: & Argentina: & Mexico: & Mexico: \\
1.1 & 0.8 & 0.8 & 0.3 & 0.5 & 0.4 & 0.1 & 0.3 \\
Venezuela: & Paraguay: & Uruguay: & Uruguay: & Uruguay: & Uruguay: & Uruguay: & Uruguay: \\
0.3 & 0.6 & 0.1 & 0.0 & 0.3 & 0.1 & 0.1 & 0.1 \\
Uruguay: & Uruguay: & Paraguay: & Paraguay: & Venezuela: & Paraguay: & Paraguay: & Paraguay: \\
0.3 & 0.2 & 0.1 & 0.0 & 0.2 & 0.0 & 0.0 & 0.0 \\
\hline
\end{tabular}

Notes: data are from IMF, 2012. The table lists countries with shares larger than $0.2 \%-0.3 \%$. The members of the Pacific Alliance are given in bold typeface.

It is fascinating to note that, despite the existence of a regional FTA, trade between some two countries is not large. Take for example the combination of Peru and Mexico. The trade between the two is quite small in per- 
centage terms, yet it increased manifold recently. The two countries signed in April 2011 a bilateral FTA effective from February 2012.

\section{Assessing Export Performance Using the Portfolio Approach}

Diversification of risk in the portfolio context emerged out of the field of finance in the 1950s, particularly attributed to the work of Markowitz ([22] [23]). Markowitz provided statistical foundation and a method for effectively reducing investment risk given the fluctuations and evolution of risky asset-markets. The diversification theory asserts that by statistically selecting a group of investment assets an investor could effectively lower the risk in the portfolio compared with the risk borne by any individual asset. Sharpe ([24]) and Lintner ([25]) provided the necessary economic structure and equilibrium arguments to subsume Markowitz's mean-variance criterion to develop a simple mathematical equation for asset-pricing, which was labelled the Capital Asset Pricing Model (CAPM) ${ }^{9}$. This became known as the Modern Portfolio Theory. The pricing model gives us the risk-return tradeoff so as to evaluate whether a risky asset would provide a rate of return commensurate with risk borne. This risk-return tradeoff of a risky asset is typically measured against that of the market as a whole, where the market is proxied by a broad-based index of risky assets. Traditionally risk has been measured in one of two ways. In the Markowitz scheme, it is the total risk, measured by the standard deviation. In the Sharpe-Lintner scheme, it is the market-based risk, measured by the beta, which is the average sensitivity of a risky asset to the fluctuations in the market as a whole. Whereas the CAPM has an important role in many contexts, the investments-related applications have made use of the empirical counterpart of the CAPM, called the Single Index Model (SIM).

Now recall that regional FTAs have been advocated to the countries of the world for trade-based economic development and growth, contrasting it from the aid-based economic development. Access to a large regional market is helpful in increasing exports and lowering fluctuations in export earnings.

Despite Mercosur's initial bold goals, the trading bloc has shown a lackluster performance, both for trade integration among its members and for promotion of its trading bloc as a unified exporting body for other nonmember countries. As a result, the trading bloc has failed to develop closer ties to dynamic economies around the globe. Instead the trading bloc has focused on developing closer ties to smaller economies in Latin America. For instance, after many years, the trading bloc is still struggling to design a bilateral trade agreement with the European Union, and has avoided closer cooperation with NAFTA. China has become a large importer of Mercosur's raw materials and commodities; however, Mercosur has failed to develop a higher penetration for its own manufactured products and knowledge-intensive products into the Chinese market. The Mercosur countries have shown levels of economic competitiveness well below the Pacific Alliance counterparts on several dimensions, viz., governmental interventions in economies, level of corruption, economic freedom, and the ease of doing business. These factors further compromise the ability of these countries to pursue a well-thought out sustainable long-term economic development plan.

The countries of the Pacific Alliance, on the other hand, have developed a number of bilateral trade agreements over the years and have shown a much higher degree of awareness for the role of the private sector in promoting their economies ${ }^{10}$. These countries also show a much higher degree of diligence in pursuing international trade alliances with dynamic economies across the globe. The implication is that they have avoided the strong ideological bias depressing the development of Mercosur members.

We wish to study the exports of the two blocs to find whether Mercosur, as the more established RFTA, has been able to develop a more efficacious export portfolio than the recently created Pacific Alliance in a risk-return perspective. In addition, we compare these two RFTAs' export portfolio to an Asian export portfolio comprised of four Asian countries, viz., Hong Kong, Indonesia, Singapore and South Korea.

We assess export performance of trading blocs as well as individual countries from the blocs in two different ways. For the period of 1988-2012 we collect annual data on total exports denominated in US dollars from the International Monetary Fund (IMF). IMF provides these data in the aggregate without breaking down the total

\footnotetext{
${ }^{9}$ The announcement is available at http://www.economia-snci.gob.mx/sic php/pages/bruselas/trade links/ing/abring2011.pdf. Details are available at http://www.sice.oas.org/Trade/MEX PER Integ_Agrmt/MEX_PER Ind_s.asp.

${ }^{10}$ The equation of CAPM is given as $E\left(R_{i}\right)=R_{f}+\left\{E\left(R_{m}\right)-R_{f}\right\} \beta_{i}$, where $E\left(R_{i}\right)$ is the expected return on asset $i$ for the next period,

$R_{f}$ is the risk-free rate, $E\left(R_{m}\right)$ is the expected return on the market portfolio and $\beta_{i}$ is the average sensitivity of asset $i$ 's returns to those of the market portfolio.
} 
exports in different product categories. We collect the data for the individual countries as well as for the whole world; this latter item will serve as the index.

The countries of Mercosur and the Pacific Alliance are thought of as assets comprising their respective blocs' export portfolios. We wish to assess the sensitivity of exports to the fluctuations in the global trade. The slope coefficient of the simple linear regression equation should capture the sensitivity. In the context of investment theory, this slope coefficient is called the beta and the regression equation is called the Single Index Model ${ }^{11}$. The estimation of the equation of the SIM is based on an index which serves as the benchmark. In this application, the benchmark is the total world exports. That a country's or a trading bloc's exports would fluctuate with total world exports (trade) does not need explanation. The estimation is based on the annual arithmetic "returns" calculated from the total exports for a country, bloc or the world.

Table 4 summarizes the mean return, standard deviation, betas, and the ratio of the mean return to standard deviation (a close variant of the Sharpe ratio ${ }^{12}$ ) and the ratio of the mean return to beta (a close variant of the Treynor ratio ${ }^{13}$ ) of each country in both export portfolios.

Table 4. Summary statistics from the single index model by country.

\begin{tabular}{cccccc}
\hline Country & $\begin{array}{c}\text { Mean } \\
\text { return (\%) }\end{array}$ & $\begin{array}{c}\text { Standard } \\
\text { deviation (\%) }\end{array}$ & Beta & $\begin{array}{c}\text { Modified } \\
\text { Sharpe ratio }\end{array}$ & $\begin{array}{c}\text { Modified Treynor } \\
\text { ratio (\%) }\end{array}$ \\
\hline Argentina & 9.13 & 14.51 & 0.99 & 0.64 & 9.22 \\
Brazil & 9.6 & 14.52 & 1.14 & 0.66 & 8.24 \\
Paraguay & & & & \\
Uruguay & 8.59 & 13.39 & 0.87 & 0.64 & 9.87 \\
Venezuela & 8.7 & 25.01 & 1.69 & 0.34 & 5.15 \\
\hline & & Pacific Alliance countries & & 8.83 \\
\hline Chile & 11.74 & 16.87 & 1.33 & 0.69 & 12.20 \\
Colombia & 11.35 & 13.83 & 0.93 & 0.82 & 16.07 \\
Mexico & 11.09 & 15.62 & 0.69 & 0.70 & 9.28 \\
Peru & 10.12 & 16.05 & 1.09 & 0.63 & 16.50 \\
\hline Hong Kong & 10.89 & 10.13 & 0.66 & 1.07 & 7.87 \\
Indonesia & 8.26 & 13.65 & 1.05 & 0.60 & 9.64 \\
Singapore & 11.28 & 13.71 & 1.17 & 0.82 & 11.75 \\
S. Korea & 11.98 & 11.96 & 1.02 & 1.00 & 8.46 \\
Index & 8.46 & 9.62 & 1.00 & 0.88 & \\
\hline
\end{tabular}

Notes: ${ }^{*}$ Data for Paraguay are not available. At the time of this research Paraguay was in a dispute that resulted in its "suspension" from Mercosur. Hence, the data for this time period did not reflect active participation in an rfta framework. Beta indicates the fluctuations of the portfolio relative to the index: a beta of one implies that the portfolio fluctuates as much as the index. Modified Sharpe ratio is defined as mean return/standard deviation. Modified Treynor ratio is defined as mean return/beta.

\footnotetext{
${ }^{11}$ A comprehensive list, with details, of various categories of agreements for various countries of the Americas (among themselves and countries of the world) can be found at the web page, Foreign Trade Information System, maintained by the Organization of American States (oas), accessible at http://www.sice.oas.org/agreements_e.asp. The agreements are categorized as 1) multilateral agreements, 2) Customs Unions, 3) Free Trade Agreements, 4) Framework Agreements, and 5) Partial Preferential Agreements.

${ }^{12}$ The equation is given as $R_{i, t}=\alpha_{i}+\beta_{i} R_{m, t}+\varepsilon_{i, t}$, where in the current context, $R_{i, t}$ is the return for country or bloc $i$ for period $t$, $R_{m, t}$ is the return for the index $m$ for period $t, \alpha_{i}$ is the intercept for country or bloc $i, \beta_{i}$ is the slope coefficient for country or block $i$, and $\varepsilon_{i, t}$ is the error term for country or bloc $i$ for period $t$.

${ }^{13}$ While we may refer to the calculated number as the modified Sharpe ratio $\left(\bar{R}_{i} / \sigma_{i}\right)$, the exact definition of the Sharpe ratio is $\left(\bar{R}_{i}-\bar{R}_{f}\right) / \sigma_{i}$, where $\bar{R}_{i}$ is the arithmetic average of the returns for country or bloc $i$ and $\bar{R}_{f}$ is the arithmetic average of the risk-free return. In the context of this study, we need not use the risk-free rate. Consequently, $\bar{R}_{f}$ may be considered equal to zero.
} 
All countries in both portfolios show exports return above the global rate of $8.46 \%$, with Uruguay showing the lowest rate of return and Chile the highest rate of return in their respective bloc. It is important to note that countries in both export portfolios also show standard deviation well above global standard deviation of 9.62\%, indicating the relative riskier nature of the exports of Mercosur and Pacific Alliance. Venezuela shows the highest volatility of export returns followed by Chile and Peru. For the ratio of mean return to standard deviation (modified Sharpe ratio), most of the countries in the sample turn out to be risky assets, with Venezuela showing the worst performance of the group and Colombia showing the best performance. Yet recognize that compared with the index, the countries of Mercosur and the Pacific Alliance have fared poorly. For the ratio of mean return to beta (modified Treynor ratio), most of the countries in the sample turn out to be risky assets as before. A majority of the countries of the two RFTAs have done better than the index; the exceptions are Brazil and Venezuela. The Mercosur FTA has a beta of 1.24 and Pacific Alliance FTA has a beta of 0.79, implying that Mercosur's exports are more affected by fluctuations in global trade than those of the Pacific Alliance. Recognize that a beta of one implies that the portfolio fluctuates as much as the index. Here Mercosur's portfolio fluctuates approximately $125 \%$ of the index whereas the Pacific Alliance's only approximately $80 \%$. The further implication is that other things being equal the Mercosur portfolio would have higher return than that of the Pacific Alliance.

The next step is to estimate the performance of export portfolios of the two trading blocs. Table 5 summarizes the results. For each trading bloc, three types of portfolios are constructed. A portfolio is mean-variance efficient if one of two conditions is met: 1) The portfolio has the highest return for a given level of variance and 2) the portfolio has the lowest variance for a given level of return. Brainard and Cooper ([26]), Paudel and Koirala

\begin{tabular}{|c|c|c|c|}
\hline Mercosur & MVP & 5th portfolio & 10th portfolio \\
\hline Return (\%) & 9.06 & 9.27 & 17.42 \\
\hline SIM std. dev. (\%) & 9.80 & 10.19 & 113.12 \\
\hline Zero beta rate (\%) & & 8.50 & 11.00 \\
\hline Modified Sharpe ratio & 0.92 & 0.91 & 0.15 \\
\hline Sharpe ratio & & 0.076 & 0.057 \\
\hline Pacific Alliance & MVP & 5th portfolio & 10th portfolio \\
\hline Return & 11.00 & 11.49 & 520.7 \\
\hline SIM std. dev. & 11.08 & 12.11 & 5105.39 \\
\hline Zero beta rate & & 8.50 & 11.00 \\
\hline Modified Sharpe ratio & 0.99 & 0.95 & 0.10 \\
\hline Sharpe ratio & & 0.247 & 0.100 \\
\hline HISSK countries & MVP & 5th portfolio & 10th portfolio \\
\hline Return & 11.04 & 15.15 & 248.91 \\
\hline SIM std. dev. & 9.70 & 15.69 & 714.39 \\
\hline Zero beta rate & & 8.50 & 11.00 \\
\hline Modified Sharpe ratio & 1.14 & 0.97 & 0.35 \\
\hline Sharpe ratio & & 0.424 & 0.333 \\
\hline
\end{tabular}

Notes: All numbers are in percentage. Mercosur countries are Argentina, Brazil, Uruguay and Venezuela. The Pacific Alliance countries are Chile, Colombia, Peru and Mexico. The HISSK countries are Hong Kong, Indonesia, Singapore and S. Korea. SIM denotes the Single Index Model. MVP denotes the Minimum Variance Portfolio from the SIM. 5th portfolio is the fifth portfolio in risk-return space from the SIM. 10th portfolio is the tenth portfolio in risk-return space from the SIM. Sharpe ratio is defined as (mean return - zero beta rate)/standard deviation. 
([27]), Du Plessis and Ward ([28]), Bergh and Van Rensbug ([29]) provide some interesting applications. A mean-variance-efficient portfolio is considered to have the best risk-return tradeoff possible. Note, however, that under the Markowitz model the risk is defined to be the total risk of a portfolio, unlike the aforementioned Single Index Model where the risk is defined in relation to a benchmark. Using the SIM method, three portfolios are formed, viz., the minimum variance portfolio (MVP), a fifth portfolio (which is the fifth portfolio, among 10, in the risk-return space) and a 10th portfolio (which is the tenth portfolio, among 10 , in the risk-return space) ${ }^{14}$. To compare the performance of these two export portfolios, we use the Sharpe Ratio where we substitute the zero-beta rate for the risk-free rate. The efficient Mercosur export portfolios show a lower performance than the Pacific Alliance efficient export portfolios ( 0.076 and 0.057 versus 0.247 and 0.100 , respectively).

In the spirit of international comparison, we wish to compare Mercosur and the Pacific Alliance with a nonLatin American export portfolio. We created a portfolio consisting of Hong Kong, Indonesia, Singapore and South Korea. For the lack of a better term, let us call it the HISSK portfolio. The HISSK portfolio dominates both Latin American portfolios on the mean-variance criterion (the Sharpe ratio of 0.424 and 0.333 for the 5th and 10th efficient export portfolios, respectively, are way superior to those of the corresponding efficient export portfolios of both RFTAs). In addition, the HISSK portfolio has a beta of 0.93 implying that it tracks the global trade more tightly than either of the Latin American blocs. Incidentally note from Table 4 that individual countries, except for Indonesia, of HISSK portfolio have done quite well compared with the index. The economic implication can be drawn that the HISSK countries collectively possess an economic system which enables them to acquire higher ability to track trends in global trade. An analysis of the elements of this system and their comparison with the Latin American trading blocs is beyond the scope of this study.

\section{Conclusions}

This study applied the Single Index Model portfolio method to assess the ability of RFTAs to manage the risks associated with international trade. The results indicate that the Pacific Alliance's export portfolio dominates Mercosur's export portfolio in a risk-return perspective. When we compare these two regional FTAs' portfolios to an Asian export portfolio, the export portfolios of the Latin American RFTAs are dominated by the Asian export portfolio in a risk-return perspective.

Regional FTAs continue to serve as the laboratory for global economic development. Export-driven economic growth may be pursued vigorously while simultaneously pursuing the concomitant variables of sustainable, widely-dispersed growth in the welfare of these countries. To put it starkly, we observe that gains from global trade in regional FTAs may have been suboptimal for the Latin American FTAs.

\section{References}

[1] Herman, D. (2013) Post-Doha Trade Governance: Atlantic Hegemony or WTO Resurgence? CIGI Policy Brief No. 3, April. Centre for International Governance Innovation. www.cigionline.org

[2] Zhang, M. (2013) 9th WTO Bali Ministerial Conference 2013: A Final Attempt to Salvage the Doha Round of WorldTrade Talks. www.ibtimes.com

[3] WTO (2013) Regional Trade Agreements. www.wto.org

[4] Dymond, W.A. (2007) Doha in the Dumps: The Bilateral Option. Eurostudia, 3, 1-17. http://dx.doi.org/10.7202/017649ar

[5] EUCE (2007) The Demise of Doha: The End of the Multilateral Trading System? The European Union Center of Excellence at the University of North Carolina, Chapel Hill.

[6] Bhagwati, J. (2013) Dawn of a New System. Finance and Development, 8-13.

[7] Fergusson, I., Cooper, W., Jurenas, R. and Williams, B. (2013) The Transpacific Partnership Negotiations and Issues for Congress. CRS Report for Congress. Congressional Research Service, Washington DC.

[8] Furby, D. (2012) Global Trade: The Fall of Doha and the Rise of Bilateral Agreements. Business for New Europe, London.

[9] Gil, J.M. (2012) From Multilateral Negotiations to Bilateral and Regional Negotiations: The Effect of Doha Stalling.

\footnotetext{
${ }^{14}$ While we may refer to the calculated number as the modified Treynor ratio $\left(\bar{R}_{i} / \beta_{i}\right)$, the exact definition of the Treynor ratio is $\left(\bar{R}_{i}-\bar{R}_{f}\right) / \beta_{i}$, where the variables are as defined before. In the context of this study, we need not use the risk-free rate.
} 
www.usergioarboleda.edu

[10] Schwab, S. (2011) After Doha: Why the Negotiations Are Doomed and What We Should Do about It. Foreign Affairs, 90, 104-117.

[11] Haas, E.B. (1964) Beyond the Nation State: Functionalism and International Organization. Stanford University Press, Stanford.

[12] Duina, F. (2007) The Social Construction of Free Trade: The EU, NAFTA, and Mercosur. Princeton University Press, Princeton.

[13] Gilpin, R. (1987) The Political Economy of International Relations. Princeton University Press, Princeton.

[14] Cooley, A. and Spruyt, H. (2009) Contracting States: Sovereign Transfers in International Relations. Princeton University Press, Princeton.

[15] Keohane, R.O. (1984) After Hegemony: Cooperation and Discord in the World Political Economy. Princeton University Press, Princeton.

[16] Mattli, W. (1999) The Logic of Regional Integration: Europe and Beyond. Cambridge University Press, Cambridge. http://dx.doi.org/10.1017/CBO9780511756238

[17] Van Ginkel, H. and Van Langenhove, L. (2003) Integrating Africa: Perspectives on Regional Integration and Development. UNU Press.

[18] Haokip, T. (2012) Recent Trends in Regional Integration and the Indian Experience. International Area Studies Review, 15, 377-392. http://dx.doi.org/10.1177/2233865912465605

[19] Chow, P.C.Y. and Ciuriak, D. (2012) The FTA Music Is Playing in Asia: After ECFA, Will Taiwan Join the Dance? International Trade Journal, 26, 61-75. http://dx.doi.org/10.1080/08853908.2012.631870

[20] Haokip, T. (2012) Recent Trends in Regional Integration and the Indian Experience. International Area Studies Review, 15, 377-392. http://dx.doi.org/10.1177/2233865912465605

[21] Fergusson, I. (2011) World Trade Organization Negotiations: The Doha Development Agenda. CRS Report for Congress. Congressional Research Service, Washington DC.

[22] Markowitz, H.G. (1952) Portfolio Selection. Journal of Finance, 7, 77-91.

[23] Markowitz, H.G. (1959) Portfolio Selection: Efficient Diversification of Investments. Yale University Press, New Haven.

[24] Sharpe, W.F. (1964) Capital Asset Prices: A Theory of Market Equilibrium under Conditions of Risk. Journal of Finance, 19, 425-442.

[25] Lintner, J. (1965) The Valuation of Risk Assets and the Selection of Risky Investments in Stock Portfolios and Capital Budgets. Review of Economics and Statistics, 47, 13-37. http://dx.doi.org/10.2307/1924119

[26] Brainard, W.C. and Cooper, R.N. (1968) Uncertainty and Diversification in International Trade. Studies in Agriculture Economics, Trade and Development, 8, 256-285.

[27] Paudel, R.B. and Koirala, S. (2006). Application of Markowitz and Sharpe Models in Nepalese Stock Market. Journal of Nepalese Business Studies, 3, 18-35.

[28] Du Plessis, A.J. and Ward, M. (2009) A Note on Applying the Markowitz Portfolio Selection Model as a Passive Investment Strategy on the JSE. Investment Analysis Journal, 69, 39-45.

[29] Bergh, G. and Van Rensburg, P. (2008) Hedge Funds and Higher Moment Portfolio Selection. Journal of Derivatives \& Hedge Funds, 14, 102-106. http://dx.doi.org/10.1057/jdhf.2008.14 